\title{
Pengaruh Tata Kelola Perusahaan, Reputasi KAP, Karakteristik Perusahaan dan Opini Audit terhadap Audit Delay
}

\author{
Hilda Azalia David M \\ Universitas Katolik Soegijapranata \\ hildaazalia@ymail.com \\ Sansaloni Butar Butar \\ Universitas Katolik Soegijapranata \\ sansaloni@unika.ac.id
}

\begin{abstract}
Financial statements may help investors in estimating firm's future performance. The sooner they are published, the more relevant the information for making investment decision. A delay in the release of financial statements may result from audit delay. Audit delay is a period of time the process of auditing measured from the date book company up to date stated in a report auditor independent. This study examines the factors that can influence the audit delay period for public companies on Indonesia Stock Exchange in 2014 to 2018. The independent variables used in this study are the existence of the governance committee, the size of the audit committee, the reputation of the firm (KAP), the company's complexity, profits and audit opinion. Employing purposive sampling method, this study collect final sample of 1866 companies which used to test the hypotheses. Using logistic regression. the evidents show that the existence of the governance committee, KAP reputation, and profit were negatively associated with audit delay. Meanwhile, firm complexity was positively associated with audit delay. In addition, the size of the audit committee has no effect on audit delay.
\end{abstract}

Keywords: audit delay, corporate governance, KAP reputation, company complexity, audit opinion.

\begin{abstract}
Abstrak
Laporan keuangan membantu investor mengestimasi kinerja perusahaan di masa depan. Semakin cepat laporan keuangan dipublikasikan maka semakin relevan digunakan dalam pengambilan keputusan investasi. Keterlambatan pelaporan keuangan bisa dipucu oleh audit delay. Audit delay adalah jangka waktu penyelesaian proses audit yang diukur dari tanggal tutup buku perusahaan hingga tanggal yang tertera pada laporan auditor independen. Penelitian ini menguji kembali faktor-faktor yang dapat mempengaruhi masa audit delay pada perusahaan publik yang terdapat di BEI tahun 2014 hingga 2018. Variabel independen yang digunakan dalam penelitian ini adalah keberadaan komite tata kelola, ukuran komite audit, reputasi KAP, kompleksitas perusahaan, laba dan opini audit. Penentuan sampel menggunakan metode purposive sampling dengan jumlah sampel akhir yang digunakan yaitu 1866 perusahaan. Analisis menggunakan regresi logistik. Hasil pengujian menunjukkan bahwa keberadaan komite tata kelola, reputasi KAP, dan laba berpengaruh negatif terhadap audit delay, dan kompleksitas perusahaan berpengaruh positif terhadap audit delay, sedangkan ukuran komite audit tidak berpengaruh terhadap audit delay.
\end{abstract}

Kata kunci: audit delay, tata kelola perusahaan, reputasi KAP, kompleksitas perusahaan, opini audit. 


\section{PENDAHULUAN}

Laporan keuangan memberikan gambaran mengenai bagaimana entitas berkembang dan menjalankan usahanya (kinerja perusahaan) dalam suatu periode. Laporan keuangan bermanfaat bagi investor untuk memprediksi kemampuan perusahaan dalam menghasilkan kas di masa mendatang. Agar bermanfaat dalam pengambilan keputusan, informasi yang terkandung dalam laporan keuangan harus relevan, dapat diandalkan (reliable), dan mudah dipahami oleh pengguna laporan keuangan (Weygandt et al., 2015). Untuk memberikan keyakinan tambahan maka laporan keuangan juga harus diaudit oleh Kantor Akuntan Publik (KAP) yang telah terdaftar di Badan Pengawas Pasar Modal (BAPEPAM). Di samping itu, perusahaan wajib menyampaikan laporan keuangan secara tepat waktu dan sesuai dengan prinsip akuntansi yang berlaku umum.

Batas waktu untuk penyampaian laporan keuangan sebelumnya sudah diatur dalam Keputusan Ketua Bapepam Nomor: Kep-346/BL/2011 yang isinya menyatakan bahwa laporan keuangan tahunan perusahaan dilaporkan maksimal akhir bulan ketiga setelah tanggal tutup buku perusahaan. Akan tetapi terdapat peraturan baru yang mengatur mengenai batas waktu penyampaian laporan keuangan, yaitu Peraturan Otoritas Jasa Keuangan Nomor:29/POJK.04/2016 yang menyatakan bahwa laporan keuangan tahunan perusahaan wajib disertai dengan laporan audit yang didalamnya terdapat pendapat yang lazim dan dilaporkan tidak lebih dari akhir bulan ke empat setelah tanggal laporan keuangan tahunan. Akan tetapi walaupun batas waktu penyampaian laporan keuangan telah diperpanjang, tetap saja masih ada perusahaan yang terlambat dalam menyampaikan laporan keuangannya. Keterlambatan publikasi laporan keuangan dapat menyebabkan informasi yang terdapat dalam laporan keuangan kehilangan relevansinya.

Apabila laporan keuangan yang telah diaudit semakin cepat dipublikasikan maka laporan keuangan tersebut akan semakin bermanfaat bagi pengguna laporan keuangan. Mengacu pada Keputusan Direksi PT Bursa Efek Indonesia Nomor : IV/Kep/BEI/2018 mengenai ketentuan khusus pencatatan saham di papan akselerasi dan Peraturan Otoritas Jasa Keuangan Nomor : 29/POJK/2016 tentang laporan tahunan emiten atau perusahaan publik, perusahaan yang terlambat menyampaikan laporan keuangan audit akan dikenai peringatan, denda dan bahkan dikenai suspensi.

Keterlambatan penyampaian laporan keuangan merupakan peristiwa yang umum terjadi di pasar modal Indonesia. Tercatat dari tahun 2001 hingga 2008 ada 922 perusahaan yang dikenai sanksi denda (economy.okezone.com). Lalu sebanyak 184 perusahaan terlambat menyampaikan laporan keuangan periode 2009 hingga 2011 (merdeka.com). Selanjutnya terdapat 52 emiten yang yang terlambat mempublikasikan laporan keuangan periode 31 Desember 2012 (idx.co.id), 48 emiten terlambat mempublikasikan laporan keuangan periode 31 Desember 2013 (idx.co.id), 52 perusahaan terlambat mempublikasikan laporan keuangan periode 31 Desember 2014 (idx.co.id). Selanjutnya terdapat 63 perusahaan yang terlambat mempublikasikan laporan keuangan periode 31 Desember 2015 (liputan6.com), 17 perusahaan terlambat mempublikasikan laporan keuangan periode 31 Desember 2016 (idx.co.id). Sedangkan tahun 2018 terdapat 10 perusahaan yang terlambat mempublikasikan laporan keuangan periode 31 Desember 2017 (idx.co.id), tahun 2019 terdapat 10 perusahaan yang terlambat menyampaikan laporan keuangan periode 31 desember 2018 (idx.co.id). Data dapat dilihat pada ilustrasi grafik di bawah ini : 


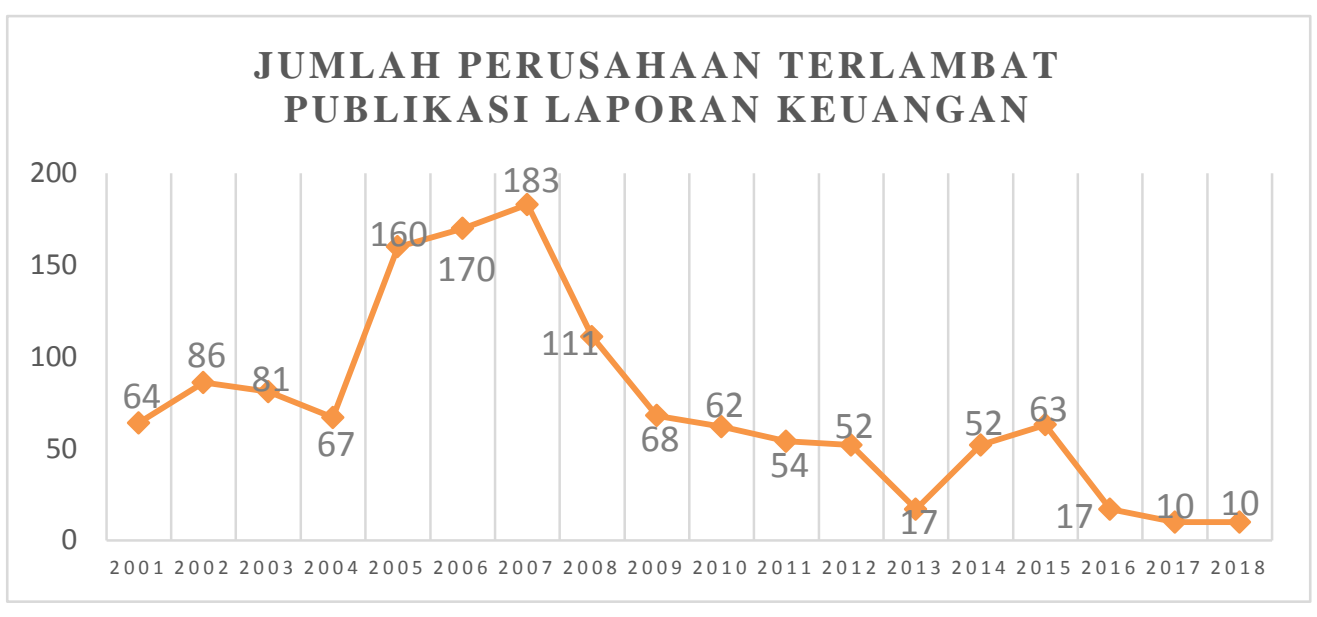

Salah satu faktor yang dapat memperlambat perusahaan dalam menyampaikan laporan keuangan ke publik adalah keterlambatan dalam merampungkan audit atau sering disebut dengan audit delay.

Fenomena audit delay telah menarik perhatian peneliti akuntansi dan berupaya untuk mencari determinan audit delay. Dari berbagai studi empiris yang dilakukan selama ini, peneliti telah mengidentifikasi beberapa faktor yang mempengaruhi audit delay. Faktorfaktor tersebut yaitu opini audit, komite audit, kompleksitas, solvabilitas, profitabilitas, penerapan IFRS, ukuran KAP (Susianto, 2017; Habib dkk., 2018; Maggy dan Diana, 2018; Handoyo dan Maulana, 2019).

Beberapa penelitian sebelumnya melaporkan bahwa tata kelola perusahaan berpengaruh terhadap audit delay, karena tata kelola perusahaan yang baik akan mengurangi kemungkinan terjadinya masalah-masalah akuntansi yang kelak akan menyulitkan auditor eksernal untuk mengidentifikasinya. Penugasan audit akan lebih lama selesai jika laporan keuangan yang akan diaudit penuh dengan kesalahan-kesalahan material. (Fama dan Jensen, 1983) menyatakan bahwa tata kelola perusahaan yang baik dapat mengurangi risiko yang timbul.

Salah satu organ tata kelola perusahaan yaitu komite audit. Komite audit yang efektif dapat mengurangi praktik pelaporan keuangan perusahaan yang tidak sesuai dengan prinsip akuntansi yang ada. Semakin banyak anggota Komite Audit maka diharapkan fungsi Komite Audit dalam menjaga kualitas laporan keuangan berjalan efektif. Apabila laporan keuangan telah disusun berdasarkan kebijakan akuntansi yang sehat maka tugas pengauditan menjadi lebih mudah dan waktu yang dibutuhkan untuk merampungkan pengauditan menjadi lebih singkat.

Reputasi KAP juga diduga berpengaruh terhadap audit delay. Kantor Akuntan Publik (KAP) yang memiliki reputasi yang baik seperti KAP Big Four dipercaya lebih cepat dalam menjalankan audit dibandingkan dengan KAP lain. Hal ini disebabkan pengalaman dan sumber daya yang jauh lebih banyak dimiliki oleh KAP Big Four ditambah dengan penggunakan teknologi audit yang memungkin mereka melakukan proses audit dengan lebih efektif.

Karakteristik perusahaan yang diaudit juga turut berkontribusi terhadap audit delay. Perusahaan yang memiliki kinerja yang baik cenderung untuk mengumumkan good news tersebut lebih cepat agar mendapat respon positif dari pasar. Terlebih untuk menunjukkan kredibilitas perusahaan. Hal ini didukung oleh penelitian dari (Susianto, 2017), dan (Zulaikha, 2016). Selain laba atau rugi, karakteristik perusahaan juga dilihat dari kompleksitas perusahaan. Perusahaan yang sudah besar membutuhkan proses audit lebih karena kompleksitasnya yang tinggi. melaporkan bahwa perusahaan yang memiliki anak perusahaan yang lebih banyak cenderung meningkatkan audit delay. 
Opini audit juga diprediksi mempengaruhi audit delay. (Aryaningsih dan Budiartha, 2014; Sumartini dan Widhiyani, 2014; Apriyani, 2015) memberi bukti bahwa opini tanpa pengecualian menurunkan audit delay. Selain komite audit, reputasi KAP, kompleksitas perusahaan dan opini audit terdapat variabel lainnya yaitu komite tata kelola perusahaan. Komite ini diduga berpengaruh terhadap audit delay.

Upaya perusahaan untuk mendorong tata kelola perusahaan yang baik dapat diwujudkan dengan membentuk Komite Tata Kelola. Sejumlah perusahaan publik diketahui telah membentuk Komite Tata Kelola. Fungsi utama komite ini adalah memastikan bahwa kebijakan, standar atau prosedur yang telah ditetapkan perusahaan ditaati di seluruh lini organisasi dan mengusulkan perbaikan-perbaikan untuk meningkatkan tata kelola yang baik. Keberadaan Komite Tata Kelola diprediksi dapat menurunkan audit delay karena kebijakan pelaporan keuangan telah sesuai dengan aturan-aturan yang ada. Waktu yang diperlukan auditor eksternal untuk memverifikasi transaksi-transaksi yang mencurigakan menjadi berkurang dan audit delay dengan sendirinya menurun.

Penelitian ini bertujuan untuk menguji kembali determinan audit delay yang telah teridentifikasi dalam penelitian terdahulu dan menambah satu variabel baru yaitu keberadaan Komite Tata Kelola. Perusahaan yang memiliki komite tata kelola memberikan sinyal positif kepada pihak luar tentang keseriusan perusahaan untuk menegakkan good corporate governance. Sampel penelitian yaitu perusahaan publik yang terdaftar di Bursa Efek Indonesia.

\section{TINJAUAN LITERATUR DAN PERUMUSAN HIPOTESIS}

\section{Keberadaan Komite Tata Kelola}

Dalam arti luas tata kelola perusahaan didefinisikan sebagai sebuah seperangkat peraturan yang mengatur hubungan antara pemegang saham, pengelola perusahaan, kreditor, karyawan, pemerintah, serta pemegang kepentingan pihak internal maupun eksternal yang berkaitan dengan hak dan kewajiban mereka, atau dapat dikatakan bahwa ini merupakan sebuah sistem yang mengarahkan serta mengendalikan sebuah perusahaan (Cadbury Committee of United Kingdom). Prinsip-prinsip tersebut yaitu akuntabilitas, transparasi, independensi, responsibilitas, dan kesetaraan.

Tata kelola perusahaan yang baik akan mengurangi munculnya tindakan tidak etis yang dapat merugikan perusahaan. Dengan adanya sistem tata kelola perusahaan yang dengan jelas mengatur semua aktivitas yang dilakukan maka tindakan-tindakan yang dapat merugikan pemegang saham dapat dihindarkan. Surya dan Yustiavanda (2006) dalam Agoes dan Ardana (2011) menyatakan bahwa tata kelola minimum memiliki empat organ untuk mendukung penerapan tata kelola. Jika terdapat tambahan organ tata kelola maka perusahaan tersebut sangat memperhatikan mekanisme tata kelola perusahaannya. Organ tambahan tersebut dapat diwujudkan dengan adanya Komite Tata Kelola.

Komite Tata Kelola adalah komite yang dibentuk oleh dewan yang bertujuan untuk memastikan bahwa praktik-praktik tata kelola yang baik telah dijalankan di lini organisasi. Keberadaan Komite Tata Kelola secara terpisah memberikan sinyal positif ke pasar bahwa perusahaan bersungguh-sungguh dan berkomitmen dalam menegakkan tata kelola perusahaan yang baik. Dengan adanya Komite Tata Kelola diharapkan fungsi pengawasan terhadap manajamen akan semakin baik dan efektif sehingga masalah akuntansi akan lebih mudah dideteksi dan tidak menghambat publikasi laporan keuangan.

Apabila tata kelola perusahaan sudah baik, maka pengendalian internalnya juga baik sehingga risiko kecurangan yang dapat terjadi semakin kecil. Salah saji material dapat ditekan atau bahkan dihilangkan. Selanjutnya, auditor eksternal yang menjalankan tugas pengauditan tidak memerlukan waktu yang lama untuk menyelesaikan tugasnya dibanding 
pengauditan pada perusahaan yang belum menerapkan tata kelola perusahaan yang baik. Dengan demikian, keberadaan Komite Tata Kelola dapat menurunkan audit delay.

Berdasarkan argumen di atas, hubungan antara keberadaan Komite Tata Kelola dan audit delay dinyatakan sebagai berikut :

\section{H1: Perusahaan yang memiliki Komite Tata Kelola lebih kecil kemungkinannya mengalami audit delay.}

\section{Ukuran Komite Audit}

Komite audit adalah sebuah komite yang dibentuk oleh Dewan Komisaris yang betugas untuk membantu Dewan dalam menjalankan tugas dan tanggungjawabnya. Sehingga komite audit diangkat dan diberhentikan oleh Dewan Komisaris. Mengacu pada Peraturan Otoritas Jasa Keuangan Nomor 55/POJK.04/2015, tugas dan tanggungjawab komite audit yaitu melakukan penelahan atas ketaatan terhadap peraturan undang-undang yang berhubungan dengan kegiatan perusahaan. Selain itu juga memiliki tugas dan tanggungjawab untuk memberikan saran kepada Dewan Komisaris terkait dengan dengan adanya potensi benturan kepentingan perusahaan. Komite audit juga merupakan salah satu organ penting dalam penerapan tata kelola perusahaan yang baik.

Komite audit diketuai oleh Komisaris Independen, dan minimum terdiri dari 3 orang yang berasal dari Komisaris Independen dan pihak luar perusahaan. Semakin banyak anggota komite audit maka kinerjanya akan semakin efektif dan efisien karena pengendaliannya juga semakin kuat. Sehingga ketika perusahaan ingin menerbitkan laporan keuangan akan lebih cepat. Jadi masa audit delay yang dialami perusahaan akan cenderung pendek.

Berdasarkan argumen dan hasil-hasil penelitian terdahulu, hubungan antara ukuran komite audit dan audit delay dinyatakan dalam hipotesis berikut ini:

\section{H2: Perusahaan yang memiliki ukuran komite audit lebih tinggi, kecil kemungkinan untuk mengalami audit delay.}

\section{Reputasi KAP}

Kantor Akuntan Publik (KAP) merupakan badan usaha yang memberikan layanan jasa yang dilakukan oleh akuntan publik. Badan usaha ini harus mendapatkan izin dari Menteri Keuangan agar dapat menjalankan kegiatannya. KAP yang ada di dunia ini terbagi menjadi KAP big four dan non big four. KAP yang mendapat predikat big four yaitu Price Waterhouse Coopers (PwC), Ernst \& Young (EY atau E\&Y), Deloitte Touche Tohmatsu (Deloitte) dan KPMG. Selain KAP tersebut, maka mendapatkan predikat KAP non big four.

Perusahaan besar cenderung memilih KAP big four karena berkaitan dengan kualitas auditnya. Perusahaan percaya bahwa kualitas audit yang diberikan oleh KAP big four lebih baik, karena ketika perusahaan diaudit oleh KAP big four dapat meningkatkan reputasi perusahaan. Selain itu juga akan menambah keyakinan para pengguna laporan keuangan mengenai hasil audit yang diberikan, karena diaudit oleh KAP big four.

KAP yang memiliki predikat big four atau yang berafiliasi dengan KAP tersebut dipercaya memiliki akuntan publik yang berkualitas dan memiliki kompetensi yang baik. Akuntan publik yang bekerja di KAP big four dipercaya dapat menyelesaikan audit lebih cepat karena memiliki kompetensi dan keahlian sehingga audit delay yang dialami perusahaan akan cenderung pendek. Semakin baik reputasi KAP maka semakin kecil kemungkinan perusahaan mengalamai audit delay.

Hubungan antara reputasi Kantor Akuntan Publik (KAP) dengan audit delay dinyatakan secara formal dalam hipotesis berikut ini:

\section{H3: Perusahaan yang diaudit oleh KAP big four lebih kecil kemungkinan untuk mengalami audit delay.}




\section{Laba/Rugi}

Laporan laba rugi merupakan laporan keuangan yang di dalamnya memberikan informasi mengenai apakah sebuah perusahaan mengalami keuntungan atau kerugian. Laba atau rugi juga dijadikan salah satu indikator untuk menilai kinerja perusahaan. Ketika perusahaan mendapatkan laba maka perusahaan dianggap berhasil dalam mengelola aset yang dimiliknya, dan juga sebaliknya apabila perusahaan mengalami kerugian maka perusahaan dianggap kurang baik dalam mengelola asetnya karena perusahaan tersebut mengalami penurunan aset bersih.

Laba atau rugi yang dialami oleh perusahaan dapat mempengaruhi durasi pelaksanaan audit. Perusahaan yang mengalami kerugian cenderung menunda publikasi laporan keuangan. Karena kerugian yang dialami perusahaan dianggap sebagai bad news dan dapat mempengaruhi pengambilan keputusan investor untuk masa yang akan datang, maka informasi rugi cenderung ditunda sedangkan laba yang didapatkan akan segera dipublikasi ke pasar. Keberhasilan suatu perusahaan dalam menghasilkan laba dianggap sebagai good news dan mendorong perusahaan untuk segera melaporkannya ke publik. Di sisi lain, saat mengaudit laporan keuangan perusahaan tersebut auditor tidak mengalami masalah-masalah pelaporan keuangan yang rumit yang dapat menyebabkan proses audit menjadi lebih panjang. Akibatnya, auditor dapat menyelesaikan penugasan audit sesuai dengan waktu yang telah disepakati dan audit delay dapat dihindari.

Berdasarkan pemikiran di atas, hubungan antara laba dengan audit delay dinyatakan sebagai berikut :

\section{H4: Perusahaan yang mendapatkan laba atau tidak mengalami kerugian lebih kecil kemungkinan untuk mengalami audit delay.}

\section{Kompleksitas perusahaan}

Seiring dengan berjalannya waktu, aktivitas bisnis yang dilakukan perusahaan menjadi lebih kompleks. Transaksi-transaksi bisnis semakin beragam dan jumlahnya juga semakin banyak. Kompleksitas perusahaan juga semakin meningkat seiring dengan bertambahnya jumlah anak perusahaan. Aktivitas perusahaan anak yang beragam dan berbeda dengan bisnis inti induk perusahaan membuat masalah-masalah pelaporan keuangan, seperti pengakuan pendapatan, menjadi semakin kompleks dibanding sebelumnya. Sebagai konsekuensi meningkatnya masalah pelaporan keuangan, waktu yang dibutuhkan seorang auditor dalam menyelesaikan penugasan audit menjadi lebih panjang. Auditor harus melakukan prosedur pemeriksaan audit yang lebih mendalam dan membutuhkan waktu yang lebih lama untuk menilai kewajaran pos-pos laporan keuangan. Kemungkinan perusahaan mengalami audit delay diprediksi juga akan semakin meningkat.

Hubungan antara jumlah anak perusahaan dan audit delay dinyatakan secara formal dalam hipotesis berikut:

\section{H5: Perusahaan dengan kompleksitas yang semakin tinggi lebih besar kemungkinannya mengalami audit delay.}

\section{Opini audit}

Opini audit adalah pendapat mengenai kewajaran yang diberikan oleh auditor yang melakukan audit laporan keuangan atas suatu perusahaan dalam suatu periode. Setelah melaksanakan proses audit, maka hasil akhir dari proses audit tersebut adalah berupa pendapat atau opini yang diberikan oleh auditor yang mengaudit. Opini audit berdasarkan SPAP (Standar Profesional Akuntan Publik) dan SA (Standar Audit), yaitu wajar tanpa pengecualian (SA 700), wajar tanpa pengecualaian dengan bahasa penjelasan, wajar dengan pengecualian (SA 705), tidak wajar dan tidak memberikan pendapat. 
Perusahaan yang menjalankan proses pelaporan keuangan yang transparan dan sesuai dengan prinsip-prinsip akuntansi yang berlaku lebih besar kemungkinannya mendapat opini wajar tanpa pengecualian dibandingkan perusahaan yang tidak transparan dan yang menerapkan kebijakan akuntansi yang tidak sesuai dengan kondisi perusahaan yang sesungguhnya. Auditor yang melakukan audit pada perusahaan yang memiliki sistem pelaporan keuangan yang transparan dan menerapkan kebijakan akuntansi yang sehat tidak akan mengalami isu-isu pelaporan keuangan yang membutuhkan upaya lebih untuk memahami dan menilainya. Akibatnya, audit delay dapat dihindari. Hal yang berbeda dialami auditor yang memeriksa laporan keuangan perusahaan yang tidak transparan. Dalam keadaan seperti ini, kecil kemungkinannya auditor memberi opini wajar tanpa pengecualian. Seorang auditor membutuhkan upaya yang lebih besar untuk menilai kewajaran transaksitransaksi yang tercatat dalam pembukuan perusahaan. Situasi akan semakin parah jika perusahaan melakukan pembatasan-pembatasan sehingga auditor harus menggunakan cara alternatif yang membutuhkan waktu yang lebih lama untuk menilai kewajaran pos-pos laporan keuangan. Akibatnya, kemungkinan terjadinya audit delay semakin tinggi.

Berdasarkan argumen dan hasil-hasil penelitian terdahulu, hubungan antara opini auditor dengan audit delay dinyatakan dalam hipotesis berikut:

\section{H6: Perusahaan yang mendapatkan opini WTP lebih kecil kemungkinannya untuk mengalami audit delay.}

\section{METODE PENELITIAN}

\section{Populasi dan Sampel Penelitian}

Populasi adalah keseluruhan dari objek penelitian yang memiliki karakteristik yang sama. Populasi dalam penelitian ini adalah semua perusahaan yang terdaftar di Bursa Efek Indonesia (BEI) tahun 2014-2018. Sampel adalah bagian dari populasi yang menjadi perhatian peneliti (Butar Butar, 2007). Pengambilan sampel dalam penelitian ini menggunakan teknik purposive sampling. Proses pemilihan sampel secara detail dapat dilihat pada Tabel 1. Total sampel yang tersedia untuk pengujian hipotesi berjumlah 1866 observasi.

Tabel 1. Proses pemilihan sampel.

\begin{tabular}{|l|c|c|c|c|c|c|}
\hline \multicolumn{1}{|c|}{ Kriteria } & $\mathbf{2 0 1 4}$ & $\mathbf{2 0 1 5}$ & $\mathbf{2 0 1 6}$ & $\mathbf{2 0 1 7}$ & $\mathbf{2 0 1 8}$ & Total \\
\hline $\begin{array}{l}\text { Jumlah perusahaan yang } \\
\text { terdaftar di Bursa Efek } \\
\text { Indonesia tahun 2014 hingga } \\
2018\end{array}$ & 509 & 525 & 539 & 562 & 619 & 2754 \\
\hline $\begin{array}{l}\text { Perusahaan yang menerbitkan } \\
\text { laporan keuangan dengan mata } \\
\text { uang asing }\end{array}$ & $(79)$ & $(84)$ & $(84)$ & $(87)$ & $(95)$ & $(429)$ \\
\hline $\begin{array}{l}\text { Perusahaan yang tidak } \\
\text { menerbitkan laporan keuangan } \\
\text { tidak berakhir tanggal 31 }\end{array}$ & $(1)$ & $(0)$ & $(0)$ & $(0)$ & $(0)$ & $(1)$ \\
Desember tersedia & $(50)$ & $(57)$ & $(76)$ & $(76)$ & $(94)$ & $(353)$ \\
\hline $\begin{array}{l}\text { Data tidak tersata memenuhi } \\
\text { persyaratan }\end{array}$ & $(12)$ & $(11)$ & $(12)$ & $(9)$ & $(10)$ & $(54)$ \\
\hline Data ekstrim Jumlah sampel & 355 & 363 & 360 & 377 & 411 & 1866 \\
\hline
\end{tabular}


Jenis data yang digunakan dalam penelitian ini adalah jenis data sekunder. Data tersebut berupa laporan keuangan perusahaan yang terdaftar di Bursa Efek Indonesia tahun 2014 hingga 2018. Sumber data penelitian ini diperoleh melalui website resmi Bursa Efek Indonesia (BEI), yaitu www.idx.co.id dan ICMD (Indonesia Capital Market Directory).

\section{Pengukuran Variabel \\ Audit delay}

Audit delay merupakan lamanya waktu penyelesaian audit yang dihitung dari tanggal tahun penutupan buku hingga tanggal laporan auditor. Dalam penelitian ini, audit delay merupakan variabel dummy yang diberi kode 0 jika tidak mengalami audit delay (perusahaan melaporkan opini audit kurang dari 120 hari) dan kode 1 jika perusahaan mengalami audit delay.

\section{Keberadaan Komite Tata Kelola}

Keberadaan komite tata kelola diukur dengan menggunakan variabel dummy. Perusahaan yang memiliki Komite Tata Kelola diberi kode 0 dan untuk perusahaan yang tidak memiliki komite tata Kelola diberi kode 1.

\section{Ukuran Komite Audit}

Varibel ini menunjukkan jumlah anggota komite audit dalam sebuah perusahaan. Variabel ini diukur dengan menggunakan jumlah anggota komite audit perusahaan (Maggy dan Diana, 2018).

\section{Reputasi KAP}

Reputasi KAP menggambarkan kualitas KAP yang mengaudit laporan keuangan perusahaan dan diukur menggunakan variabel dummy. KAP yang tidak berafiliasi dengan Big Four diberi kode 0 dan KAP yang berafiliasi dengan KAP Big Four diberi kode 1..

\section{Laba/Rugi}

Laba atau rugi merupakan jumlah laba atau rugi yang diperoleh perusahaan dalam suatu periode. Variabel ini merupakan variabel dummy yang diberi kode 0 jika perusahaan melaporkan kerugian dan 1 jika perusahaan membukukan laba.

\section{Kompleksitas perusahaan}

Kompleksitas perusahaan menggambarkan sejauh mana perusahaan terlibat dalam aktivitas bisnis yang kompleks. Variabel ini diukur dengan jumlah anak perusahaan yang dimiliki perusahaan.

\section{Opini audit}

Opini audit merupakan pendapat yang diberikan auditor atas kewajaran suatu laporan keuangan perusahaan. Variabel ini merupakan variabel dummy yang diberi kode 0 jika perusahaan mendapat qualified opinion dan 1 jika mendapat opini unqualified opinion (Susianto, 2017).

\section{Variabel kontrol}

Penelitian ini menggunakan tiga variabel kontrol, yaitu return on asset, debt to equity ratio dan ukuran perusahaan (diukur menggunakan ln total asset). Variabel-variabel tersebut mewakili perbedaan dalam karakteristik perusahaan yang dimasukkan ke dalam model pengujian hipotesis untuk mengontrol pengaruh variabel lain yang tidak menjadi perhatian dalam penelitian yang dapat mempengaruhi hasil penelitian. 


\section{Model penelitian}

Regresi logistik adalah model regresi non linier yang menggunakan fungsi eksponensial dalam penduga parameternya (Gani and Amalia, 2018). Penelitian ini menggunakan model regresi logistik.

Model yang digunakan adalah :

$$
\begin{aligned}
\operatorname{Ln} \frac{A D}{1-A D}= & \beta_{0}+\beta_{1} \text { KOMTATA }+\beta_{2} A C S I Z E+\beta_{3} K A P+\beta_{4} L A B A+\beta_{5} S U B \\
& +\beta_{6} \text { OPINI+ } \beta_{7} R O A+\beta_{8} D E R+\beta_{9} S I Z E
\end{aligned}
$$

Keterangan :

$\begin{array}{ll}\text { AD } & =\text { Audit Delay } \\ \text { KOMTATA } & =\text { Keberadaan komite tata kelola } \\ \text { ACSIZE } & =\text { Ukuran komite audit } \\ \text { KAP } & =\text { Reputasi KAP } \\ \text { LABA } & =\text { Laba } \\ \text { SUB } & =\text { Kompleksitas perusahaan } \\ \text { OPINI } & =\text { Opini audit }\end{array}$

\section{HASIL DAN PEMBAHASAN}

\section{Statistik Deskriptif}

Statistik deskriptif memberikan gambaran tentang pala penyebaran variabel-variabel dalam penelitian ini yang dilihat dari nilai rata-rata (mean), nilai minimum, nilai maksimum, dan standar devisiasi. Sampel akhir yang digunakan dalam penelitian berjumlah 1866 observasi dari tahun 2014 hingga 2018. Tabel 2 menyajikan statistik deskriptif untuk variabel-variabel yang terdapat dalam penelitian ini yang terkait dengan perusahaan yang mengalami delay maupun tidak delay.

Variabel lainnya yang menggunakan data kategorikal seperti audit delay, reputasi KAP, laba dan opini audit dideskripsikan menggunakan frekuensi. Variabel-variabel tersebut merupakan variabel dummy, yaitu 0 dan 1 sehingga kurang tepat jika menggambarkannya dengan menggunakan rata-rata, standar devisiasi, nilai minimum, dan nilai maksimum. Maka untuk mendeskripsikannya dapat dilihat dari frekuensi masing-masing variabel tersebut. Tabel 3 dan Tabel 4 menyajikan frekuensi dari masing-masing variabel yang menggunakan katagorikal untuk semua perusahaan.

Dari Tabel 2 dapat dilihat bahwa sampel dalam penelitian ini terbagi dalam dua kelompok, yaitu 81 perusahaan yang mengalami audit delay dan 1785 perusahaan tidak mengalami audit delay (non delay). Jadi total sampel dalam penilitian ini sebanyak 1866 perusahaan. Tabel tersebut menunjukkan bahwa total perusahaan yang mengalami audit delay lebih sedikit dibandingkan dengan perusahaan yang tidak mengalami delay. Jika dibuat persentase maka perbandingannya sebesar $4,34 \%$ untuk perusahaan yang mengalami delay dan $95,66 \%$ yang tidak mengalami delay.

Variabel ACSIZE atau ukuran komite audit yang diukur dengan jumlah anggota komite audit. Untuk perusahaan yang mengalami audit delay memiliki nilai minimum sebesar 3,00 lalu nilai maksimum sebesar 4,00 dan nilai rata-rata 3,05. Ini artinya perusahaan yang mengalami delay paling sedikit memiliki jumlah komite audit minimum 3 anggota (PT. ADES Tbk tahun 2014) dan maksimal 4 anggota (PT. AISA Tbk pada tahun 2014). Berbeda dengan perusahaan yang tidak mengalami delay, jumlah komite auditnya minimum 3 anggota 
(PT. AALI Tbk tahun 2014) orang dan maksimum 5 anggota (PT. BBTN Tbk tahun 2014) dengan nilai rata-rata 3,11 . Secara keseluruhan rata-rata jumlah anggota komite audit yang dimiliki oleh perusahaan yaitu 3 anggota.

Variabel SUB atau kompleksitas perusahaan yang diukur dengan menggunakan jumlah anak perusahaan yang dimiliki oleh perusahaan induk. Dari tabel 4.1 terlihat bahwa perusahaan yang tidak mengalami delay memiliki nilai rata-rata sebesar 8,65 dan nilai minimum sebesar 0 (PT. AGRO Tbk tahun 2014) lalu nilai maksimum sebesar 87 (PT. BHIT Tbk tahun 2016). Sedangkan perusahaan yang mengaami delay memiliki nilai mean sebesar 14,69 lalu nilai minimum sebesar 0 (PT. ADES Tbk tahun 2014) dan maksimum sebesar 201 (PT. LPKR tahun 2018), artinya semakin banyak jumlah anak perusahaan yang dimiliki perusahaan induk maka tingkat kecenderungan untuk mengalami delay meningkat.

Tabel 2. Statistik deskriptif.

\begin{tabular}{|c|c|c|c|c|c|c|}
\hline \multirow{3}{*}{ VARIABEL } & KATAGORI & $\mathrm{N}$ & Min & Maks & Mean & $\begin{array}{c}\text { Std. } \\
\text { Deviasi }\end{array}$ \\
\hline \multirow{4}{*}{ ACSIZE } & DELAY & 81 & 3 & 4 & 3,05 & 0,22 \\
\cline { 2 - 7 } & NO DELAY & 1785 & 3 & 5 & 3,11 & 0,36 \\
\cline { 2 - 7 } & TOTAL & 1866 & 3 & 5 & 3,10 & 0,35 \\
\hline \multirow{4}{*}{ SUB } & DELAY & 81 & 0 & 201 & 14,69 & 29,95 \\
\cline { 2 - 7 } & NO DELAY & 1785 & 0 & 87 & 8,65 & 13,64 \\
\cline { 2 - 7 } & TOTAL & 1866 & 0 & 201 & 8,91 & 14,76 \\
\hline \multirow{4}{*}{ DEA } & DELAY & 81 & $-393,32$ & 111,97 & $-11,97$ & 52,10 \\
\cline { 2 - 7 } & NO DELAY & 1785 & $-1088,94$ & 71,60 & 2,64 & 27,65 \\
\cline { 2 - 7 } & TOTAL & 1866 & $-1088,94$ & 111,97 & 2,00 & 29,26 \\
\cline { 2 - 7 } & DELAY & 81 & $-391,79$ & 162,19 & $-3,18$ & 47,80 \\
\cline { 2 - 7 } & NO DELAY & 1785 & $-8,34$ & 39,49 & 1,83 & 2,64 \\
\cline { 2 - 7 } & TOTAL & 1866 & $-391,79$ & 162,19 & 1,61 & 10,28 \\
\hline \multirow{3}{*}{ SIZE } & DELAY & 81 & 20,66 & 37,06 & 27,94 & 2,59 \\
\cline { 2 - 7 } & NO DELAY & 1785 & 22,38 & 34,44 & 28,62 & 1,84 \\
\cline { 2 - 7 } & TOTAL & 1866 & 20,66 & 37,06 & 28,59 & 1,88 \\
\hline
\end{tabular}

Sumber: data yang diolah

Variabel kontrol return on asset (ROA) diukur dengan menggunakan rasio perbandingan anatara laba dengan total aset. Perhitungan ROA dimaksudkan untuk mengetahu kemampuan perusahaan dalam mengelola aset untuk menghasilkan laba. Dari tabel 4.1 di atas dapat diketahui bahwa perusahaan yang mengalami delay memiliki nilai minimum sebesar -393,32 (PT. MTFN Tbk tahun 2016) dan nilai maksimum sebesar 111,97 (PT. SKYB Tbk tahun 2016) dengan nilai rata-rata -11,97. Sedangkan perusahaan yang tidak mengalami delay memiliki nilai minimum sebesar -1088,94 (PT. TRIO Tbk tahun 2015) dan nilai maksimum sebesar 71,60 (PT. LPIN Tbk tahun 2017) dengan nilai rata-rata 2,64. ROA yang bernilai negatif mengindikasikan bahwa kemampuan perusahaan tersebut dalam menghasilkan laba dengan aset yang dimiliknya masih kurang baik. Secara keseluruhan ratarata ROA perusahaan sebesar 2,00.

Variabel kontrol debt to equity (DER) diukur dengan menggunakan rasio perbandingan antara liabilitas dengan ekuitas. Perhitungan DER dimaksudkan untuk mengukur kemampuan 
perusahaan untuk melunasi kewajibannya. Tabel 4.1 menunjukkan bahwa rata-rata untuk perusahaan yang mengalami delay sebesar -3,18 lalu nilai minimum sebesar -391,79 (PT. MTFN Tbk tahun 2017) dan nilai maksimum sebesar 162,19 (PT. ETWA Tbk tahun 2016). Terlihat bahwa nilai mean perusahaan yang mengalami delay bernilai negatif, artinya liabilitas perusahaan tersebut bernilai negatif dan perusahaan kesulitan untuk membayarkan kewajibannya. Sedangkan nilai rata-rata perusahaan yang tidak mengalami delay sebesar 1,83 lalu nilai minimum sebesar -8,34 (PT. RMBA Tbk tahun 2014) dan nilai maksimum sebesar 39,49 (PT. CPRO Tbk tahun 2016). Secara keseluruhan rasio DER perusahaan memiliki nilai rata-rata sebesar 1,61 .

Variabel kontrol SIZE atau ukuran perusahaan diukur dengan logaritma natural total aset. Perusahaan yang mengalami delay memiliki nilai minimum sebesar 20,66 (PT. LAPD Tbk tahun 2014) lalu nilai maksimum sebesar 37,06 (PT. HITS Tbk tahun 2014) dan nilai rata-rata sebesar 27,94. Sedangkan perusahaan yang tidak mengalami delay memiliki nilai minimum sebesar 22,38 (PT. ZBRA Tbk tahun 2018) lalu nilai maksimum sebesar 34,44 (PT. BMRI Tbk tahun 2015) dan nilai rata-rata sebesar 28,62. Terlihat bahwa dari nilai rata-rata ukuran perusahaan yang tidak mengalami delay lebih besar dibandingkan perusahaan yang mengalami audit delay. Secara keseluruhan rata-rata ukuran perusahaan yaitu sebesar 28,59.

Tabel 3. Crosstabulation Kom_Tata.

\begin{tabular}{|c|c|c|c|c|c|}
\hline & & & \multicolumn{2}{|c|}{ DELAY } & \multirow[b]{2}{*}{ Total } \\
\hline & & & Tidak Delay & Delay & \\
\hline \multirow[t]{8}{*}{ Kom_Tata } & Memiliki & Count & 115 & 6 & 121 \\
\hline & & $\%$ within KOM_TATA & $95,0 \%$ & $5,0 \%$ & $100,0 \%$ \\
\hline & & \% within DELAY & $6,4 \%$ & $7,4 \%$ & $6,5 \%$ \\
\hline & & $\%$ of Total & $6,2 \%$ & $0,3 \%$ & $6,5 \%$ \\
\hline & Tidak Me & Count & 1670 & 75 & 1745 \\
\hline & & $\%$ within KOM_TATA & $95,7 \%$ & $4,3 \%$ & $100,0 \%$ \\
\hline & & $\%$ within DELAY & $93,6 \%$ & $92,6 \%$ & $93,5 \%$ \\
\hline & & $\%$ of Total & $89,5 \%$ & $4,0 \%$ & $93,5 \%$ \\
\hline \multirow[t]{4}{*}{ Total } & & Count & 1785 & 81 & 1866 \\
\hline & & $\%$ within KOM_TATA & $95,7 \%$ & $4,3 \%$ & $100,0 \%$ \\
\hline & & $\%$ within DELAY & $100,0 \%$ & $100,0 \%$ & $100,0 \%$ \\
\hline & & $\%$ of Total & $95,7 \%$ & $4,3 \%$ & $100,0 \%$ \\
\hline
\end{tabular}

Sumber: output SPSS

Dari tabel 3 di atas menunjukkan hasil bahwa total sampel sebanyak 1866 perusahaan. Perusahaan yang tidak memiliki komite tata kelola sebanyak 1745 atau sebesar 93,5\%. Sedangkan perusahaan yang memiliki komite tata kelola sebanyak 121 atau sebesar 6,5\%. Jadi dapat diketahui bahwa perusahaan yang tidak memiliki komite tata kelola lebih banyak dibandingkan dengan perusahaan yang tidak memiliki komite tata kelola.

Perusahaan yang memiliki komite tata kelola dan mengalami peristiwa delay sebanyak 6 perusahaan atau sebesar 7,4\%, sedangkan untuk perusahaan yang tidak memiliki komite tata kelola dan mengalami peristiwa delay sebanyak 75 perusahaan atau sebesar $92,6 \%$. Secara keseluruhan dapat diketahui bahwa perusahaan yang memiliki komite tata kelola kecenderungan untuk mengalami peristiwa delay lebih rendah yaitu sebesar 6,5\%, dibandingkan dengan perusahaan yang tidak memiliki komite tata kelola sebesar 93,5\%. 
Tabel 4. Crosstabulation KAP, LABA dan OPINI

\begin{tabular}{|c|c|c|c|c|c|}
\hline & & & \multicolumn{2}{|c|}{ DELAY } & \multirow[b]{2}{*}{ Total } \\
\hline & & & $\begin{array}{l}\text { Tidak } \\
\text { delay }\end{array}$ & Delay & \\
\hline \multirow[t]{12}{*}{ KAP } & \multirow[t]{4}{*}{ Non big four } & Count & 1159 & 66 & 1225 \\
\hline & & $\%$ within KAP & $94,6 \%$ & $5,4 \%$ & $100,0 \%$ \\
\hline & & $\%$ within DELAY & $64,9 \%$ & $81,5 \%$ & $65,6 \%$ \\
\hline & & $\%$ of Total & $62,1 \%$ & $3,5 \%$ & $65,6 \%$ \\
\hline & \multirow[t]{4}{*}{ Big four } & Count & 626 & 15 & 641 \\
\hline & & $\%$ within KAP & $97,7 \%$ & $2,3 \%$ & $100,0 \%$ \\
\hline & & $\%$ within DELAY & $35,1 \%$ & $18,5 \%$ & $34,4 \%$ \\
\hline & & $\%$ of Total & $33,5 \%$ & $0,8 \%$ & $34,4 \%$ \\
\hline & \multirow[t]{4}{*}{ Total } & Count & 1785 & 81 & 1866 \\
\hline & & $\%$ within KAP & $95,7 \%$ & $4,3 \%$ & $100,0 \%$ \\
\hline & & $\%$ within DELAY & $100,0 \%$ & $100,0 \%$ & $100,0 \%$ \\
\hline & & $\%$ of Total & $95,7 \%$ & $4,3 \%$ & $100,0 \%$ \\
\hline \multirow[t]{12}{*}{ Laba } & \multirow[t]{4}{*}{ Rugi } & Count & 363 & 42 & 405 \\
\hline & & $\%$ within LABA & $89,6 \%$ & $10,4 \%$ & $100,0 \%$ \\
\hline & & $\%$ within DELAY & $20,3 \%$ & $51,9 \%$ & $21,7 \%$ \\
\hline & & $\%$ of Total & $19,5 \%$ & $2,3 \%$ & $21,7 \%$ \\
\hline & \multirow[t]{4}{*}{ Laba } & Count & 1422 & 39 & 1461 \\
\hline & & $\%$ within LABA & $97,3 \%$ & $2,7 \%$ & $100,0 \%$ \\
\hline & & $\%$ within DELAY & $79,7 \%$ & $48,1 \%$ & $78,3 \%$ \\
\hline & & $\%$ of Total & $76,2 \%$ & $2,1 \%$ & $78,3 \%$ \\
\hline & \multirow[t]{4}{*}{ Total } & Count & 1785 & 81 & 1866 \\
\hline & & $\%$ within LABA & $95,7 \%$ & $4,3 \%$ & $100,0 \%$ \\
\hline & & $\%$ within DELAY & $100,0 \%$ & $100,0 \%$ & $100,0 \%$ \\
\hline & & $\%$ of Total & $95,7 \%$ & $4,3 \%$ & $100,0 \%$ \\
\hline \multirow[t]{12}{*}{ Opini } & \multirow[t]{4}{*}{ Selain WTP } & Count & 15 & 11 & 26 \\
\hline & & $\%$ within OPINI & $57,7 \%$ & $42,3 \%$ & $100,0 \%$ \\
\hline & & $\%$ within DELAY & $0,8 \%$ & $13,6 \%$ & $1,4 \%$ \\
\hline & & $\%$ of Total & $0,8 \%$ & $0,6 \%$ & $1,4 \%$ \\
\hline & \multirow[t]{4}{*}{ WTP } & Count & 1770 & 70 & 1840 \\
\hline & & $\%$ within OPINI & $96,2 \%$ & $3,8 \%$ & $100,0 \%$ \\
\hline & & $\%$ within DELAY & $99,2 \%$ & $86,4 \%$ & $98,6 \%$ \\
\hline & & $\%$ of Total & $94,9 \%$ & $3,8 \%$ & $98,6 \%$ \\
\hline & \multirow[t]{4}{*}{ Total } & Count & 1785 & 81 & 1866 \\
\hline & & $\%$ within OPINI & $95,7 \%$ & $4,3 \%$ & $100,0 \%$ \\
\hline & & $\%$ within DELAY & $100,0 \%$ & $100,0 \%$ & $100,0 \%$ \\
\hline & & $\%$ of Total & $95,7 \%$ & $4,3 \%$ & $100,0 \%$ \\
\hline
\end{tabular}


Sementara itu, dari tabel 4 dapat dilihat bahwa total sampel sebanyak 1866 perusahaan. Perusahaan yang diaudit oleh KAP non big four sebanyak 1225 atau sebesar 65,6\%, sedangkan perusahaan yang diaudit oleh KAP big four sebanyak 641 atau sebesar 34,4\%. Jadi dapat diketahui bahwa perusahaan yang diaudit oleh KAP non big four lebih banyak dibandingkan dengan perusahaan yang diaudit oleh KAP big four.

Perusahaan yang diaudit oleh KAP non big four mengalami peristiwa delay sebanyak 66 perusahaan atau sebesar $81,5 \%$, sedangkan untuk perusahaan yang diaudit oleh KAP big four dan mengalami peristiwa delay sebanyak 15 perusahaan atau sebesar $18,5 \%$. Terlihat bahwa perusahaan yang diaudit oleh KAP big four memiliki kecenderungan yang lebih kecil untuk mengalami delay dibandingkan oleh perusahaan yang diaudit oleh KAP non big four.

Dari tabel 4 di atas menunjukkan bahwa total sampel sebanyak 1866 perusahaan. Perusahaan yang mendapatkan laba sebanyak 1461 atau sebesar 78,3\% sedangkan perusahaan yang mengalami kerugian sebanyak 405 atau sebesar $21,7 \%$. Jadi dapat diketahui bahwa perusahaan yang mendapatkan laba lebih banyak dibandingkan dengan perusahaan yang mengalami kerugian.

Perusahaan yang mendapatkan laba dan mengalami peristiwa delay sebanyak 39 atau sebesar $48,1 \%$ sedangkan untuk perusahaan yang mengalami kerugian dan mengalami peristiwa delay sebanyak 42 atau sebesar 51,9\%. Terlihat bahwa perusahaan yang mendapatkan laba memiliki kecenderungan lebih kecil mengalami delay dibandingkan perusahaan yang mengalami kerugian.

Dari tabel 4 di atas menunjukkan bahwa total sampel sebanyak 1866 perusahaan. Perusahaan yang mendapatkan opini wajar tanpa pengecualian sebanyak 1840 atau sebesar $98,6 \%$ sedangkan perusahaan yang mendapatkan opini selain wajar tanpa pengecualian sebanyak 26 atau sebesar 1,4\%. Jadi dapat diketahui bahwa perusahaan yang mendapatkan opini wajar tanpa pengecualian lebih banyak dibandingkan dengan perusahaan yang mendapatkan opini selain wajar tanpa pengecualian.

Perusahaan yang mendapatkan opini wajar tanpa pengecualian dan tidak mengalami peristiwa delay sebanyak 1770 atau sebesar 99,2\% sedangkan untuk perusahaan yang mendapatkan opini selain wajar tanpa pengecualian dan tidak mengalami peristiwa delay sebanyak 15 atau sebesar $0,8 \%$. Terlihat semakin baik opini yang didapatkan maka kecenderungan perusahaan untuk mengalami audit delay lebih kecil.

Tabel 5 menyajikan kemampuan prediktif model dan kelayakan model. Dari Tabel 5 terlihat bahwa kemampuan model regresi untuk mengklasifikasikan data penelitian sebesar 95,7\%. Artinya model regresi sudah cukup baik dalam mengklasifikasikan data penelitian. Hasil dari omnimbust test yang menunjukkan bahwa nilai signifikansi sebesar 0,000 lebih kecil dari 0,05 .

Tabel 5. Hasil Uji Klasifikasi.

\begin{tabular}{|l|c|c|c|c|l|}
\hline Pengujian & $\begin{array}{l}\text { Classifica } \\
\text { tion table }\end{array}$ & $\begin{array}{c}\text { GoF } \\
\text { Test }\end{array}$ & $\begin{array}{c}\text { Omnimbus } \\
\text { Test }\end{array}$ & $\begin{array}{l}\text { Nag. R } \\
\text { Square }\end{array}$ & \multicolumn{1}{|c|}{ Keterangan } \\
\hline Pengklasifikasian & 95,7 & & & & Model layak \\
\hline $\begin{array}{l}\text { Omnimbus test of } \\
\text { model coefficients }\end{array}$ & & & 0,000 & & Model regresi fit \\
\hline $\begin{array}{l}\text { Nagelkerke R } \\
\text { Square }\end{array}$ & & & & 15,6 & $\begin{array}{l}\text { Kemampuan variabel } \\
\text { independent menjelaskan } \\
\text { variabel dependen sebesar } \\
15,6 \% \text {. }\end{array}$ \\
\hline $\begin{array}{l}\text { Goodness of Fit } \\
\text { Test }\end{array}$ & 0,373 & & & Model regresi sudah tepat \\
\hline
\end{tabular}


Artinya model regresi fit. Dan layak untuk dilakukan pengujian selanjutnya. Nilai dari Nagelkerke R Square dalam penelitian ini sebesar 0,156 atau 15,6\%. Artinya kemampuan variabel independen dalam menerangkan variabel dependen sebesar 15,6\% dan sisanya sebesar 84,4\% dijelaskan oleh variabel lain di luar model penelitian. Hasil pengujian Hosmer and Lemeshow Test menunjukkan nilai signifikansi sebesar 0,373 lebih besar dari 0,05 yang artinya tidak terdapat perbedaan signifikan antara model dengan nilai yang diobservasi atau model yang dibentuk sudah tepat.

\section{HASIL DAN PEMBAHASAN}

Penerimaan atau penolakan hipotesis dapat dilihat dari nilai signifikansinya. Variabel independen berpengaruh signifikan apabila nilai signifikansinya kurang dari 0,05 . Tabel 6 menyajikan hasil pengujian hipotesis dengan regresi logistik.

Tabel 6. Hasil Regresi Logistik

\begin{tabular}{|c|c|c|c|c|c|c|c|c|}
\hline Variabel & B & SE & Wald & Df & Sig & Sig/2 & $\operatorname{Exp}(\mathrm{B})$ & Ket. \\
\hline KOMTATA & $-8,12$ & 0,468 & 3,014 & 1 & 0,083 & 0,0415 & 0,444 & Ditolak \\
\hline ACSIZE & $-2,11$ & 0,482 & 0,191 & 1 & 0,662 & 0,331 & 0,810 & Ditolak \\
\hline KAP & $-0,546$ & 0,328 & 2,768 & 1 & 0,096 & 0,048 & 0,579 & Diterima \\
\hline LABA & $-1,243$ & 0,249 & 24,857 & 1 & 0,000 & 0,000 & 0,289 & Diterima \\
\hline SUB & 0,022 & 0,006 & 12,480 & 1 & 0,000 & 0,000 & 1,022 & Diterima \\
\hline OPINI & $-2,266$ & 0,473 & 22,998 & 1 & 0,000 & 0,000 & 0,104 & Diterima \\
\hline ROA & 0,000 & 0,002 & 0,026 & 1 & 0,872 & 0,436 & 1,000 & - \\
\hline DER & $-0,015$ & 0,009 & 2,812 & 1 & 0,094 & 0,047 & 0,985 & - \\
\hline SIZE & $-0,109$ & 0,071 & 2,308 & 1 & 0,129 & 0,065 & 0,897 & - \\
\hline Constant & 4,272 & 2,365 & 3,264 & 1 & 0,071 & 0,036 & 71,651 & - \\
\hline
\end{tabular}

Sumber: output SPSS

\section{Keberadaan Komite Tata kelola dan Audit Delay}

Berdasarkan hasil pengujian yang ditampilkan dalam Tabel 6 dapat dilihat bahwa variabel keberadaan Komite Tata Kelola berpengaruh negatif terhadap audit delay karena nilai signifikansinya kurang dari 0,05 . Perlu dicatat bahwa variabel keberadaan Komite Tata Kelola merupakan variabel dummy yang bernilai 1 jika tidak memiliki Komite Tata Kelola dan 0 jika sebaliknya. Jadi arah negatif mengandung arti bahwa perusahaan yang tidak memiliki Komite Tata Kelola cenderung tidak mengalami audit delay. Hasil ini bertentangan dengan yang diprediksi hipotesis satu. Dengan demikian H1ditolak.

Komite Tata Kelola adalah komite yang dibentuk oleh dewan yang bertujuan untuk memastikan bahwa praktik-praktik tata kelola yang baik telah dijalankan di lini organisasi. Keberadaan Komite Tata Kelola secara terpisah memberikan sinyal positif ke pasar bahwa perusahaan bersungguh-sungguh dan berkomitmen dalam menegakkan tata kelola perusahaan yang baik. Dengan adanya Komite Tata Kelola diharapkan fungsi pengawasan terhadap manajamen akan semakin baik dan efektif sehingga masalah akuntansi akan lebih mudah dideteksi dan tidak menghambat auditor dalam menyelesaikan penugasan audit. Namun, hasil pengujian tidak mendukung argumen ini. Bahkan sebaliknya bahwa keberadaan Komite Tata Kelola dapat meningkatkan kemungkinan terjadinya audit delay.

\section{Ukuran Komite Audit dan Audit Delay}

Berdasarkan hasil pengujian di Tabel 6 dapat dilihat bahwa variabel ukuran komite audit tidak terdukung secara statistik, karena nilai signifikansinya lebih besar dari alpha 0,05. 
Ini artinya bahwa ukuran komite audit tidak berpengaruh terhadap audit delay. Dengan demikan $\mathrm{H} 2$ ditolak.

Walaupun ditolak, hasil penelitian ini mendukung temuan Faishal dan Hadiprajitno (2015) yang menyimpulkan bahwa semakin besar ukuran komite audit tidak secara nyata dapat menurunkan masa audit delay perusahaan. Dilihat dari rata-rata jumlah komite audit yang dimiliki perusahaan yaitu tiga orang, jumlah anggota komite audit yang dimiliki sudah mematuhi peraturan Bapepam yang mengharuskan sekurang-kurangnya komite audit terdiri dari tiga anggota. Ukuran komite audit bukan menjadi faktor utama penentu keefektifan kinerja komite audit (Widyaswari dan Suardana, 2014). Komite audit juga tidak ikut secara langsung dalam proses pengauditan. Salah satu peran komite audit yaitu menunjuk auditor eksternal, melakukan pengawasan terhadap kinerja mereka sampai pada pelaporan laporan keuangan. Jika terjadi perbedaan dengan manajemen, maka disinilah peran komite audit diperlukan sebagai penengah.

Menurut Zaluki dan Hussin (2010) jumlah anggota komite audit yang besar belum tentu dapat bekerja secara efektif dan menciptakan tata kelola perusahaan yang baik. Semakin banyak jumlah anggota komite audit akan semakin sulit untuk berkoordinasi atau membentuk jaringan komunikasi dengan baik, karena terdapat banyak suara dan dapat memicu timbulnya selisih pendapat antar anggota sehingga akan lebih sulit untuk mencari kata mufakat. Di samping itu semakin banyak jumlah anggota komite audit juga dapat memicu ketergantungan antar anggota dimana anggota satu bergantung kepada anggota lainnya dalam menjalankan fungsi pengawasan. Maka dari itu semakin banyak jumlah anggota komite audit belum tentu dapat menentukan keefektifitasan kinerjanya.

Di sisi lain, komite audit sudah seharusnya melakukan tugas dan tanggungjawabnya secara maksimal. Baik itu beranggotakan tiga orang atau lebih dari tiga orang. Jadi bukan berarti komite audit yang beranggotakan tiga orang kinerja kurang efektif dan yang memiliki banyak anggota bekerja semakin efektif. Karena berapapun jumlah anggotanya, komite audit memang harus menjalankan tugas dan kewajibannya secara maksimal untuk menerapkan dan menegakkan tata kelola yang baik.

\section{Reputasi Auditor dan Audit Delay}

Berdasarkan hasil pengujian di Tabel 6 dapat dilihat bahwa variabel reputasi KAP terdukung secara statistik, karena nilai signifikansinya lebih kecil dari alpha 0,05. Ini artinya bahwa reputasi KAP berpengaruh negatif terhadap audit delay. Dengan demikian H3 diterima.

Kantor Akuntan Publik (KAP) merupakan badan usaha yang memberikan layanan jasa yang dilakukan oleh akuntan publik. Reputasi KAP yang ada di dunia ini terbagi menjadi dua yaitu big four dan non big four. Perusahaan besar cenderung memilih KAP big four karena berkaitan dengan kualitas auditnya. Perusahaan percaya bahwa kualitas audit yang diberikan oleh KAP big four lebih baik, karena ketika perusahaan diaudit oleh KAP big four dapat meningkatkan reputasi perusahaan.

Selain itu juga akan menambah keyakinan para pengguna laporan keuangan mengenai hasil audit yang diberikan, karena diaudit oleh KAP big four. Disisi lain KAP yang memiliki predikat big four atau yang berafiliasi dengan KAP tersebut dipercaya memiliki akuntan publik yang lebih berkualitas dan memiliki kompetensi yang lebih baik. Sehingga dipercaya akuntan publik yang bekerja di KAP big four dipercaya dapat menyelesaikan audit lebih cepat karena memiliki kompetensi dan keahlian sehingga audit delay yang dialami perusahaan akan cenderung pendek. Sehingga semakin baik reputasi KAP maka masa audit delaynya cenderung semakin pendek. Hasil penelitian ini konsisten dengan Larasati dan Nursiam (2017) serta Lucyanda dan Nura'ni (2013) yang menunjukkan bahwa reputasi KAP berpengaruh negatif terhadap audit delay. 


\section{Laba dan Audit Delay}

Berdasarkan hasil pengujian di Tabel 6 dapat dilihat bahwa variabel laba terdukung secara statistik, karena nilai signifikansinya lebih kecil dari alpha 0,05. Ini artinya bahwa laba berpengaruh negatif terhadap audit delay. Dengan demikian H4 diterima.

Temuan ini konsisten dengan hasil penilitian Ningsih dan Widhiyani (2015) dan Puspitasari dan Sari (2012) yang menunjukkan bahwa perusahaan yang membukukan laba positif cenderung mengalami audit delay yang singkat. Ketika perusahaan mendapatkan laba, maka perusahaan (Givolvy dan Palmon, 1982) mengungkapkan bahwa informasi laba yang terdapat dalam laporan keuangan dapat mempengaruhi ketepatan waktu. Laba yang dianggap sebagai good news ini akan sesegera mungkin dipublikasikan oleh pihak perusahaan karena ingin memberikan sinyal positif kepada pasar. Semakin besar laba yang didapatkab maka masa audit delay perusahaan tersebut cenderung lebih singkat dibandingkan dengan perusahaan yang mengalami kerugian.

\section{Kompleksitas Perusahaan dan Audit Delay}

Berdasarkan hasil pengujian di Tabel 6 dapat dilihat bahwa variabel kompleksitas perusahaan terdukung secara statistik karena nilai signifikansinya lebih kecil dari alpha 0,05. Ini artinya bahwa kompleksitas perusahaan berpengaruh positif terhadap audit delay. Dengan demikian H5 diterima. Temuan ini konsisten dengan Zulaikha (2016), Puspitasari (2016) dan Hariani dan Darsono (2014).

Semakin besar perusahaan maka akan semakin kompleks juga operasionalnya. Anak perusahaan akan mendukung operasional perusahaan induk. Akan tetapi ketika perusahaan induk memiliki anak perusahaan yang banyak maka dapat memicu timbulnya keterlambatan publikasi laporan keuangan. Sehingga jumlah anak perusahaan yang semakin banyak dapat membuat masa audit delay perusahaan cenderung semakin lama. Karena auditor harus melakukan pemeriksaan audit mengenai pos-pos yang lebih kompleks sehingga memerlukan waktu lebih karena harus menyelesaikan lebih banyak dibandingkan dengan perusahaan yang memiliki jumlah anak sedikit atau bahkan tidak memiliki anak perusahaan.

\section{Opini Audit dan Audit Delay}

Berdasarkan hasil pengujian di Tabel 6 dapat dilihat bahwa variabel opini audit terdukung secara statistik karena nilai signifikansinya lebih kecil dari alpha 0,05. Ini artinya bahwa opini audit berpengaruh negatif terhadap audit delay. Dengan demikian H6 diterima.

Konsisten dengan penelitian Aryaningsih dan Budiartha (2014), temuan ini menunjukkan bahwa perusahaan yang mendapatkan opini selain Wajar Tanpa Pengecualian menyebabkan auditor bekerja lebih lama untuk mencari bukti penyebabnya. Pencarian bukti audit akan memakan waktu lebih sehingga mengindikasikan terjadinya audit delay yang semakin panjang. Hasil ini juga konsisten dengan Apriyani (2015), Sumartini dan Widhiyani (2014). Semakin baik opini audit maka tingkat kecenderungan perusahaan akan mengalami delay semakin rendah. Perusahaan yang memiliki opini audit wajar tanpa pengecualian cenderung ingin sesegera mungkin untuk mempublikasikan hasil laporan auditnya. Hal ini dikarenakan perusahaan ingin memberikan sinyal good news kepada para pengguna laporan keuangan khususnya para pemegang saham. Berbeda dengan perusahaan yang mendapatkan opini selain wajar tanpa pengecualian, ini merupakan bad news yang akan disimpan oleh perusahaan. Perusahaan akan berusaha untuk menyimpan atau menutupi bad news ini, dan menyebabkan masa audit delay perusahaan akan semakin panjang. 


\section{KESIMPULAN DAN SARAN}

\section{Kesimpulan}

Penelitian ini adalah penelitian empiris mengenai audit delay, dengan tujuan untuk mengetahui pengaruh dari tata kelola perusahaan, reputasi KAP, karakteristik perusahaan dan opini audit terhadap audit delay. Kesimpulan dari penelitian ini yaitu:

1. Perusahaan yang memiliki komite tata kelola lebih kecil kemungkinannya mengalami audit delay.

2. Ukuran komite audit tidak mempengaruhi masa audit delay yang dialami perusahaan.

3. Perusahaan yang diaudit oleh KAP big four lebih kecil kemungkinannya mengalami audit delay.

4. Perusahaan yang mendapatkan laba lebih kecil kemungkinannya mengalami audit delay.

5. Semakin tinggi kompleksitas sebuah perusahaan maka lebih tinggi kemungkinannya mengalami audit delay.

6. Semakin baik opini audit yang didapatkan perusahaan maka lebih kecil kemungkinannya mengalami audit delay.

\section{Saran}

Penelitian selanjutnya dapat menambah variabel independen baru lainnya yang diduga berperngaruh terhadap audit delay, yaitu management delay. Management delay merupakan jumlah hari antara tanggal yang tertera di laporan auditor dan rapat umum tahunan ketika laporan keuangan yang diaudit disajikan kepada publik. Berdasarkan peraturan dari POJK Nomor: 32/POJK04/2014 mengenai penyelenggaraan RUPS tahunan yang diselenggarakan maksimal 6 bulan setelah tutup buku perusahaan. Maka pelaksanaan RUPS tidak perlu untuk ditunda. Semakin cepat RUPS dilaksanakan maka masa audit delay yang dialami perusahaan diduga akan semakin pendek, karena manajemen harus mempertanggungjawabkan kinerjanya kepada para pemegang saham secepat mungkin.

\section{DAFTAR PUSTAKA}

Agoes, S. dan I.C. Ardana. 2011. Etika Bisnis dan Profesi : Tantangan Membangun Manusia Seutuhnya. Revisi. Jakarta Selatan: Salemba Empat.

Ahmad-Zaluki, N. A. dan W.N Wan-Hussin. 2010. Corporate governance and earnings forecasts accuracy, Asian Review of Accounting. doi: 10.1108/13217341011046006.

Apriyani, N. N. 2015. Pengaruh Solvabilitas, Opini Auditor, Ukuran KAP, dan Komite Audit terhadap Audit Delay. Universitas Udayana. Available at: http://ejurnal.unisri.ac.id/index.php/Akuntansi/article/view/1062/914.

Butar Butar, S. 2007. Modul Statistik dan Aplikasi SPSS. Universitas Katolik Soegijapranata, Semarang.

Economy.okezone.com. Diakses 8 September 2019. Available at: https://economy.okezone.com/read/2008/09/02/21/142237/

Eksandy, A. 2017. Pengaruh Ukuran Perusahaan, Solvabilitas, Profitabilitas Dan Komite 
Audit Terhadap Audit Delay (Pada Perusahaan Properti dan Real Estate yang Terdaftar di Bursa Efek Indonesia Pada Tahun 2012-2015). Competitive Jurnal Akuntansi dan Keuangan. doi: 10.1002/ejsp.2570.

Fama, E. F. dan M, Jensen. 1983. Separation of ownership and Control. Journal of Law and Economics 301-325.

Gani, I. dan S, Amalia. 2018. Alat Analisis Data. Revisi. Edited by P. Christian. Yogyakarta: Penerbit ANDI.

Givolvy, D. dan D, Palmon. 1982. Timeliness of Annual Earnings Announcements: Some Empirical Evidence. The Accounting Review, 486-508.

Habib, A., Md. Borhan Uddin Bhuiyan, H. J. Huang, and M. S. Miah. 2018. Determinants of audit report lag: A meta-analysis. International Journal of Auditing, 20-44.

Halim, V. 2000. Faktor-Faktor yang Mempengaruhi Audit Delay: Studi Empiris pada Perusahaan-perusahaan di Bursa Efek Jakarta. Jurnal Bisnis dan Akuntansi, pp. 63-75.

Handoyo, S. dan E.D Maulana. 2019. Determinants of Audit Report Lag of Financial Statements in Banking Secto. Jurnal Manajemen, Strategi Bisnis dan Kewirausahaan. doi: 10.24843/matrik:jmbk.2019.v13.i02.p02.

Hariani, D. dan Darsono 2014. Faktor-Faktor Pemengaruh Audit Report Lag. Diponegoro Journal of Accounting, 1-9.

Hersugondo dan A. Kartika. 2013. Prediksi Probabilitas Audit Delay Dan Faktor Determinannya, Jurnal Ekonomi Manajemen Akuntansi, 1-21.

Keputusan Direksi PT Bursa Efek Indonesia Nomor : IV/Kep/BEI/2018. Ketentuan Khusus Pencatatan Ssaham Di Papan Akselarasi.

Keputusan Ketua BAPEPAM-LK Nomor KEP-431/BL/2012.

Larasati, E. dan Nursiam. 2017. Pengaruh Ukuran KAP, Leverage, Opini Audit, Ukuran Perusahaan Terhadap Audit Delay. Universitas Muhammadiyah Surakarta. Available at: http://eprints.ums.ac.id/id/eprint/56907

Lucyanda, J. dan S.P Nura'ni. 2013. Pengujian Faktor-Faktor yang Mempengaruhi Audit Delay. Jurnal Akuntansi dan Auditing. doi: 10.14710/jaa.v9i2.5992.

Maggy and P. Diana. 2018. Accounting and finance review internal and external determinants of audit delay: evidence from Indonesian manufacturing companies. Acc. Fin. Review, 16-25.

Ningsih, I. G. A. P. S. dan N.L.S Widhiyani. 2015. Pengaruh Ukuran Perusahaan, Laba Operasi, Solvabilitas Dan Komite Audit Pada Audit Delay. E-Jurnal Akuntansi, 481- 
495.

Merdeka.com. Diakses 15 April 2019. Available at: https://www.merdeka.com/uang/54emiten-terlambat-sampaikan-laporan-keuangan-2011.html.

Peraturan Otoritas Jasa Keuangan Nomor:29/POJK.04/2016.Laporan Tahunan Emiten atau Perusahaan Publik PERATURAN OTORITAS JASA KEUANGAN NOMOR 29 /POJK.04/2016.

Peraturan Otoritas Jasa Keuangan Nomor 55 /Pojk.04/2015. Tentang Pembentukan Dan Pedoman Pelaksanaan Kerja Komite Audit.

Puspitasari, D. N. 2016. Pengaruh Ukuran Perusahaan, Anak Perusahaan, Profitabilitas, Leverage, Dan Ukuran KAP Terhadap Audit Delay. Diakses dari http://eprints.ums.ac.id/id/eprint/43409

Rianti, N. dan M. Sari. 2014. Karakteristik Komite Audit Dan Audit Delay. E-Jurnal Akuntansi. Available at: https://ojs.unud.ac.id/index.php/Akuntansi/article/view/8342.

Sastrawan, I. dan M. Latrini. 2016. Pengaruh Profitabilitas, Solvabilitas, Dan Ukuran Perusahaan Terhadap Audit Report Lag Pada Perusahaan Manufaktur. E-Jurnal Akuntansi, 311-337.

Septariani, D. 2016. Pengaruh return on assets, debt to equity ratio dan ukuran kantor akuntan publik terhadap audit delay. Journal of Applied Business and Economics, 331344.

Sumartini, N. dan N. Widhiyani. 2014. Pengaruh Opini Audit, Solvabilitas, Ukuran Kap Dan Laba/Rugi Terhadap Audit Report Lag. E-Jurnal Akuntansi, 392-409.

Susianto, S. N. 2017. Pengaruh Penerapan Wajib IFRS, Jenis Industri, Rugi, Anak Perusahaan, Ukuran KAP, Ukuran Perusahaan, Opini Audit, dan Ukuran Komite Audit Terhadap Audit Report Lag (ARL) (Studi empiris pada perusahaan yang terdaftar di BEI periode tahun 2009 -2013). Universitas Katolik Soegijapranata. Available at: http://repository.unika.ac.id/id/eprint/14701

Weygandt, J. J., P.D Kimmel, dan D.E Kieso. 2015. Financial Accounting. 3e edn. Wiley.

Widyaswari, K. dan K. Suardana. 2014. Pengaruh Karakteristik Komite Audit Terhadap Timeliness Pelaporan Keuangan: Perusahaan Go Public Yang Terdaftar Di Bursa Efek Indonesia. E-Jurnal Akuntansi, 154-166.

Zulaikha, R. 2016. Analisis Faktor internal Perusahaan yang Memengaruhi Audit delay Pada Perusahaan Pertambangan yang Terdaftar di BEI (Studi Empiris pada Perusahaan Pertambangan yang Terdaftar di BEI pada Tahun 2010-2014). Skripsi. Universitas Negeri Yogyakarta. Available at: http://eprints.uny.ac.id/id/eprint/31793. 